\title{
HERBICIDAL ACTIVITY IN MAIZE FIELDS
}

\author{
Emad El-Din M.A. Marzouk \\ Department of Plant Protection, Faculty of Agriculture, \\ Al-Azhar University, Cairo, Egypt. \\ emadahmad96@yahoo.com \\ Key Words: Maize, Weeds, Herbicides, Handhoeing, Yield \\ components, Grain yield.
}

\begin{abstract}
Field experiments were conducted during 2016 and 2017 seasons at Motubus District, Khafr El-Sheikh Governorate, to evaluate the efficacy of Starane (fluroxypyr $20 \% \mathrm{EC}$ ) at $200 \mathrm{~cm}^{3} \mathrm{fed}^{-1}$., Gesaprim (atrazine $90 \% \mathrm{WP}$ ) at $600 \mathrm{gm} \mathrm{fed}^{-1}$., Equip (foramisulfuron $22.5 \% \mathrm{EC}$ ) at $750 \mathrm{ml} \mathrm{fed}^{-1}$., Titus (rimsulfuron $25 \% \mathrm{DF}$ ) at $20 \mathrm{gm} \mathrm{fed}^{-1}$., Merline Extra (isoxaflutole $75 \% \mathrm{WG}$ ) at $50 \mathrm{gm} \mathrm{fed}^{-1}$.) and handhoeing on density and biomass of weeds, yield and yield components of maize crop compared to untreated control. Results showed that the predominant weed species during the two studied seasons were Portulaca oleracea, Corchorus olitorius, Xanthium brasilicum and Convuluvulus arvensis as broadleaved weeds, and Echinochloa colonum as grassy weed. Broadleaved weeds showed more dominant than grassy weed during the two seasons. Results also showed that all tested herbicides and hand hoeing had significant herbicidal activity against predominant weeds during the two tested seasons over unweeded control. Generally, fluroxypyr, atrazine and foramisulfuron herbicides were the most effective treatments in reducing density and biomass of weeds, as well as increasing yield components and grain yield of maize crop during the two tested seasons.
\end{abstract}

\section{INTRODUCTION}

Maize (Zea mays L.) is the most important cereal crop in Egypt and around the world, after wheat and rice. Maize is the most widely grown crop in Egypt. Maize is used as human food, animal's and poultry feed, and in industrial products, (Bibi et al., 2010). Maize also produces raw materials for starch industry and used in the preparation of other products. Maize plants are greatly affected by weeds. Weeds delay corn female flowering and maturation and reduce corn leaf area, biomass, plant height, and biomass partitioning (Evans, 2003).Moreover, weeds compete with the crop plants for space, light, moisture, nutrients and carbon dioxide, which reduced not only the yield, grain quality and 
hinder harvest operations but also increase the cost of production (Rutta et al., 1991and Rana, 2017). Excessive growth of weeds in maize field leads to $66 \%$ to $80 \%$ reduction in crop yield (Adigun, 2001, Ford and Pleasant, 1994). Weeds pose severe problems for crop husbandry and infest fallow land, reducing the soil about two hundred and eighty different types of weeds have been recorded in NWFP with varying infestation status (Lehoczky and Nagy, 2002). Chemical control method is quick, more effective, time and labour saving method than others. Success of weeds control methods depends upon several factors; however, the weed emergence pattern, application timing and stage of crop (Hoverstad et al., 2004). Therefore, this study aimed to evaluate the efficacy of certain herbicides and handhoeing in controlling weeds and their effect on yield components and grain yield of maize crop under field condition in the summer 2016 and 2017 seasons.

\section{MATERIALS AND METHOD}

Herbicidal activity was evaluated by the application of pre and/ or post-emergence herbicides in comparison with standard herbicide (Starane), hand hoeing and untreated control in maize crop during 2016 and 2017 seasons at Motobis districts, Khafr El-Sheikh Governorate. The experiments were designed as a randomized complete block design (RCBD) and each treatment was replicated three times with plot size $21 \mathrm{~m}^{2}$. Maize seeds (Triple hybrid cv. 310) were sown in 25 May and 3 June in the two successive seasons, respectively. Pre-emergence herbicides were applied after sowing and before irrigation, while, postemergence herbicides were applied at 30 days after sowing (DAS). All tested herbicides were applied using knapsack sprayer using $200 \mathrm{~L}$ water per feddan. Handhoeing treatment was done at 20 and 40 DAS.

Table (1): Herbicidal treatments, their rates and time of application in maize field during 2016 and 2017 seasons

\begin{tabular}{|c|c|c|c|}
\hline Common names & Trade names & Rate fed $^{-1}$. & Time of application \\
\hline Fluroxypyr & Starane $20 \%$ EC & $200 \mathrm{~cm}^{3}$ & Post-emergence \\
\hline Atrazine & $\begin{array}{l}\text { Gesaprim } 90 \% \\
\text { WG }\end{array}$ & $600 \mathrm{~g}$ & Pre-emergence \\
\hline foramisulfuron & Equip $22.5 \%$ EC & $750 \mathrm{ml}$ & Post-emergence \\
\hline rimsulfuron & Titus 25\%DF & $20 \mathrm{~g}$ & pre-emergence \\
\hline isoxaflutole & $\begin{array}{l}\text { Merline Extra } 75 \% \\
\text { WG }\end{array}$ & $50 \mathrm{~g}$ & Pre-emergence \\
\hline hand hoeing & --- & Twice & 20 and 40 DAS \\
\hline untreated & --- & --- & --- \\
\hline
\end{tabular}


Parameters on weed density (No. of weeds $\mathrm{m}^{-2}$ ), weed biomass (fresh weights $\mathrm{gm} \mathrm{m}^{-2}$ ), were recorded by landing a quadrate of $0.25 \mathrm{x}$ $0.25 \mathrm{~m}^{2}$ randomly four times at each plot area, then all weeds inside the quadrate were collected, identified, counted, weighed, classified and following parameters were determined as follow:-

Weed density $=$ average number of each weed.

Weed density $\%=$ average number of each weed / average number of total weeds $\mathrm{x} 100$.

Weed biomass $=$ Average fresh weight of each weed $\mathrm{gm} \mathrm{m}^{-2}$.

Weed biomass $\%=$ average fresh weight of each weed / average fresh weight of total weeds x 100 .

Weed control efficiency $=\frac{\mathrm{C}-\mathrm{T}}{\mathrm{C}} \times 100$

Where:

$\mathrm{C}=$ Mean weed fresh weight in each untreated plots.

$\mathrm{T}=$ Mean weed fresh weight in each treated plots.

At harvest, 10 plants were randomly selected from the central area of each plot. All cobs were removed from the selected plants, using a pair of manual shears, dried under the sun light for 4-days under natural condition, their length $(\mathrm{cm})$ and weight $(\mathrm{kg})$ were measured. Maize grain $\left(\mathrm{kg} \mathrm{plot}^{-1}\right)$ was also recorded, and the increase percent in maize grain yield was determined as follow:-

Increase $\%=\mathrm{T}-\mathrm{C} / \mathrm{T} \times 100$

Where:

$\mathrm{T}=$ Mean maize grain in treatment.

$\mathrm{C}=$ Mean maize grain in untreated check.

Statistical Analysis of the data were subjected to the analysis of variance (ANOVA) technique using MSTATC statistical software followed by means separation for their significant differences using the least significant differences (LSD) test according to Steel and Torrie (1980).

\section{Weed density (No.m $\left.{ }^{-2}\right)$}

\section{RESULTS AND DISCUSSION}

Results indicated that the predominant weed species found in the experimental area were four broadleaved weeds, Portulcea olericea, Corichorus olitorious, Convulvulus arvensis and Xanthium brasilicum, and one grassy weed, Echonochloa colonum during the two studied seasons (Tables 2, 3 and 4). These results are in agreement with those reported by (Youssef, 1998; Tahir et al., 2009; Mukherje and Rai, 
2015; Kakade et al., 2016; Stanzen et al., 2016 and Kumar et al., 2017). Moreover, results illustrated that broadleaved weeds were the most predominant weeds during the two tested seasons. Among the broadleaved weeds, Xanthium brasilicum recorded highest weed density in the first season, while, Corichorus olitorious was highest in the second season. The highest weed density was recorded in control treatment (13.33, 15.66, 11, 17.66 and 22.66 weed $\mathrm{m}^{-2}$ for Portulcea olericea, Corichorus olitorious, Convulvulus arvensis, Xanthium brasilicum and Echonochloa colonum, respectively, in the first season, and 17.66, 19, $16.33,14$ and 20 plant $\mathrm{m}^{-2}$, respectively, in the second season.

Table (2): Broadleaved weeds density and biomass in maize crop during 2016and 2017 winter seasons.

\begin{tabular}{|c|c|c|c|c|c|c|c|c|}
\hline \multirow[b]{2}{*}{$\begin{array}{c}\text { Weed } \\
\text { species }\end{array}$} & \multicolumn{4}{|c|}{2016} & \multicolumn{4}{|c|}{2017} \\
\hline & $\begin{array}{c}\text { Weed } \\
\text { density } \\
\text { No.m. }^{2}\end{array}$ & $\begin{array}{c}\% \\
\text { from } \\
\text { total } \\
\text { weeds }\end{array}$ & $\begin{array}{c}\text { Weed } \\
\text { biomass } \\
\left(\mathrm{g} \mathrm{m}^{-2}\right)\end{array}$ & $\begin{array}{c}\% \\
\text { from } \\
\text { total } \\
\text { weeds }\end{array}$ & $\begin{array}{c}\text { Weed } \\
\text { density } \\
\text { No.m. }^{2}\end{array}$ & $\begin{array}{c}\% \\
\text { from } \\
\text { total } \\
\text { weeds }\end{array}$ & $\begin{array}{c}\text { Weed } \\
\text { biomass } \\
\left(\mathrm{g} \mathrm{m}^{-2}\right)\end{array}$ & $\begin{array}{c}\% \\
\text { from } \\
\text { total } \\
\text { weeds }\end{array}$ \\
\hline $\begin{array}{c}\text { Portulacea } \\
\text { oleracea }\end{array}$ & 13.33 & 16.60 & 80.33 & 19.20 & 17.66 & 20.30 & 89.33 & 20.26 \\
\hline $\begin{array}{c}\text { Corchorus } \\
\text { olitorius }\end{array}$ & 15.66 & 19.50 & 79.66 & 19.04 & 19.00 & 21.84 & 90.66 & 20.56 \\
\hline $\begin{array}{l}\text { Convulvulu } \\
\text { s arvensis }\end{array}$ & 11.00 & 13.70 & 66.66 & 15.93 & 16.33 & 18.77 & 87.00 & 19.73 \\
\hline $\begin{array}{l}\text { Xanthium } \\
\text { brasilicum }\end{array}$ & 17.66 & 21.99 & 91.33 & 21.83 & 14.00 & 16.09 & 83.33 & 18.90 \\
\hline $\begin{array}{c}\text { Echonochlo } \\
\text { a colonum }\end{array}$ & 22.66 & 28.22 & 100.33 & 23.98 & 20.00 & 22.99 & 90.66 & 20.56 \\
\hline Total weeds & 80.31 & --- & 418.31 & --- & 86.99 & --- & 440.98 & --- \\
\hline
\end{tabular}

\section{Effect of herbicides and handhoeing on weed density $\left(\right.$ No.m $\left.^{-2}\right)$}

Data in (Tables 2, 3 and 4) indicated that all tested herbicides and handhoeing significantly reduced broadleaved weed density over unweeded check during the both tested seasons. Results showed that Starane and Epuip herbicides significantly $(p=0.05)$ gave maximum reduction in broadleaved weeds density in 2016 season, they gave 7.00 and 10.33 weeds $\mathrm{m}^{-2}$, respectively, while, Starane and Gesaprim recorded lowest numbers in the 2017 season, they registered 15 and 15.99 weeds $\mathrm{m}^{-2}$, respectively. However, Merline Extra and Titus recorded a moderate reduction in the numbers of broad-leaved weeds compared to untreated plots during these studies. Handhoeing treatment gave poor reduction in density of broadleaved weeds during the both seasons. 
Table (3): Effect of herbicidal treatments on weed density $\left(\mathrm{No.m}^{-2}\right)$ and weed biomass $\left(\mathrm{g} \mathrm{m}^{-2}\right)$ in maize crop during 2016 season.

\begin{tabular}{|c|c|c|c|c|c|c|c|c|c|c|c|c|c|c|c|c|}
\hline \multirow{2}{*}{ Treatments } & \multirow{2}{*}{ Rate/fed. } & \multicolumn{3}{|c|}{ Portulacea oleracea } & \multicolumn{3}{|c|}{ Corchorus olitorius } & \multicolumn{3}{|c|}{ Convulvulus arvensis } & \multicolumn{3}{|c|}{ Xanthium brasilicum } & \multicolumn{3}{|c|}{ Echonochloa colonum } \\
\hline & & W.D.* & W.B.*** & R. $\%$ & W.D & W.B. & R.\% & W.D. & W.B. & R.\% & W.D. & W.B. & R.\% & W.D & W.B. & R.\% \\
\hline Starane & $200 \mathrm{~cm} 3$ & 0.00 & 0.00 & 100 & 2.00 & 3.33 & 95.81 & 3.00 & 5.00 & 92.49 & 2.66 & 3.00 & 96.71 & 4.33 & 9.33 & 90.70 \\
\hline Gesaprim & $600 \mathrm{~g}$ & 4.00 & 5.00 & 93.77 & 3.00 & 4.33 & 94.56 & 2.00 & 3.33 & 95.00 & 3.46 & 4.67 & 94.88 & 7.33 & 13.66 & 86.38 \\
\hline Equip & $750 \mathrm{ml}$ & 3.00 & 5.00 & 93.77 & 3.33 & 8.33 & 89.54 & 2.00 & 6.33 & 90.50 & 2.00 & 3.33 & 96.71 & 3.00 & 4.33 & 95.68 \\
\hline Titus & $25 \mathrm{~g}$ & 6.66 & 18.67 & 76.75 & 7.33 & 22.00 & 72.38 & 7.33 & 16.00 & 75.99 & .5 .33 & 13.33 & 85.40 & 8.44 & 17.33 & 82.72 \\
\hline Merline Extra & $50 \mathrm{~g}$ & 6.00 & 15.66 & 80.50 & 5.66 & 17.33 & 78.24 & 9.00 & 18.66 & 72.00 & 5.00 & 11.66 & 87.23 & 8.00 & 15.00 & 85.04 \\
\hline Handhoeing & Twice & 8.00 & 23.00 & 71.36 & 7.33 & 19.00 & 76.14 & 9.00 & 25.00 & 62.49 & 6.33 & 20.33 & $\mathbf{7 7 . 7 4}$ & 11.33 & 29.66 & $\mathbf{7 0 . 4 3}$ \\
\hline Untreated & -----. & 13.33 & 80.33 & ----- & 15.66 & 79.66 & ----- & 11.00 & 66.66 & --- & 17.66 & 91.33 & $--\cdot$ & 22.66 & 100.33 & ----- \\
\hline L.S.D. $0.05 \%$ & & 1.53 & 2.74 & & 3.11 & 3.58 & & 1.17 & 2.45 & & 1.76 & 4.08 & & 3.00 & 4.10 & \\
\hline
\end{tabular}

W.D.* = weed density (No. $\left.\mathrm{m}^{-2}\right)$.

W.B. $* *=$ weed biomass $\left(\mathrm{gm} \mathrm{m}^{-2}\right)$

R. ${ }^{\circ} \%=$ Weed Control efficiency.

Table (4): Effect of herbicidal treatments on weed density $\left(\right.$ No.m $\left.{ }^{-2}\right)$ and weed biomass $\left(\mathrm{g} \mathrm{m}^{-2}\right)$ in maize crop during 2017 season.

\begin{tabular}{|c|c|c|c|c|c|c|c|c|c|c|c|c|c|c|c|c|}
\hline \multirow{2}{*}{ Treatments } & \multirow{2}{*}{$\begin{array}{c}\text { Rate/fe } \\
\text { d. }\end{array}$} & \multicolumn{3}{|c|}{ Portulacea oleracea } & \multicolumn{3}{|c|}{ Corchorus olitorius } & \multicolumn{3}{|c|}{ Convulvulus arvensis } & \multicolumn{3}{|c|}{ Xanthium brasilicum } & \multicolumn{3}{|c|}{ Echonochloa colonum } \\
\hline & & W.D*. & W.B.*** & R. $\%$ & W.D & W.B. & R.\% & W.D. & W.B. & R.\% & $\begin{array}{l}\text { W.D } \\
\end{array}$ & W.B. & R.\% & W.D. & W.B. & R.\% \\
\hline Starane & $\begin{array}{l}200 \\
\mathrm{~cm} 3\end{array}$ & 2.00 & 4.00 & 95..52 & 4.00 & 6.67 & 92.64 & $\mathbf{5 0 . 0 0}$ & 8.00 & 90.80 & 4.00 & 7.33 & 91.20 & 6.33 & 11.33 & 87.50 \\
\hline Gesaprim & $600 \mathrm{~g}$ & 3.00 & 4.33 & 95.15 & 3.33 & 7.00 & 92.27 & 5.66 & 10.33 & 88.50 & 4.00 & 8.00 & 90.39 & 6.00 & 10.00 & 88.96 \\
\hline Equip & $750 \mathrm{ml}$ & 5.30 & 10.00 & 88.80 & 7.00 & 15.67 & 82.71 & 4.33 & 8.66 & 90.04 & 3.66 & 7.00 & 91.59 & 3.00 & 5.33 & 94.12 \\
\hline Titus & $25 \mathrm{~g}$ & 8.65 & 20.33 & 77.24 & 6.00 & 23.66 & 73.90 & 13.33 & 25.33 & 70.88 & 7.00 & 17.99 & 78.41 & 7.33 & 15.66 & 82.72 \\
\hline Merline Extra & $50 \mathrm{~g}$ & 7.33 & 19.66 & 77.99 & 10.66 & 24.33 & 73.16 & 9.66 & 23.66 & 72.80 & 6.00 & 15.66 & 81.20 & 6.00 & 13.00 & 85.66 \\
\hline Handhoeing & Twice & 11.33 & 27.00 & 69.77 & 14.33 & 36.66 & 59.56 & 13.66 & 33.00 & 68.06 & 10.33 & 23.34 & 61.19 & 13.00 & 27.66 & 69.49 \\
\hline Untreated & --.--- & 17.66 & 89.33 & --- & 19.00 & 90.66 & -.- & 16.33 & 87.00 & $\begin{array}{ll}-- \\
-\end{array}$ & 14.00 & 83.33 & $-\cdots$ & 20.00 & 90.66 & --- \\
\hline L.S.D $0.05 \%$ & & 3.11 & 4.16 & & 3.29 & 4.11 & & 2.83 & 3.94 & & 2.69 & 3.53 & & 3.34 & 4.74 & \\
\hline
\end{tabular}

W.D.* = weed density $\left(\right.$ No. $\left.\mathrm{m}^{-2}\right)$.

W.B. $* *$ = weed biomass $\left(\mathrm{gm} \mathrm{m}^{-2}\right)$

R. ${ }^{\circ} \%=$ Weed control efficiency. 
Concerning grassy weed, Echonochloa colonum was identified during the two studied seasons. Obtained results showed that Starane and Equip treatments were found to be the most options in decreasing numbers of this weed, they gave 4.33 and 3.66 plant $\mathrm{m}^{-2}$, respectively, in the first season, and 4.33 and 3.00 plant $\mathrm{m}^{-2}$, respectively, in the second season (Tables 3, 4 and 5). Gesaprim and Merline Extra herbicides were gave moderate reduction in Echonochloa colonum density especially in the second season. Hand hoeing treatment gave the lowest reduction in density of Echonochloa colonum compared to untreated control in 2016 and 2017 seasons.

Density of the total weeds was affected by all herbicidal treatments. Untreated control recorded higher total weed density during the two studied seasons, it gave 80.30 and 86.99 weed $\mathrm{m}^{-2}$.While, Starane, Gesaprim and Equip herbicides were the best options in reducing total weed density during these studies (Tables 3, 4 and 5). On contrary. Titus, Merline Extra treated plots and hand hoeing treatment registered minimum reduction in density of the total weeds compared to untrated treatment. These results are in agreement with those obtained by Hafeezullah (2000), Tahir et al. (2009), Abdelmonem and El-kholy (2006) who concluded that various weed control treatments significantly affected weed density in maize fields. The main possible reason in reducing weed density in treated plots is due to applied of chemical herbicides, while, handhoeing resulted in mechanical injury to maize plants.

These results about the difference in the efficiency of various weed control practices are supported by Bogdan et al. (2002) and Janjic et al. (2004). The suppression in weed density by manual hoeing could be attributed to uprooting and mechanical injury of weeds and the differentiation in weeds in the chemically treated plots might have been difference in the mode of action which significantly controlled the weeds over control treatments. These results are in line with those reported by Skoko and Zivanovic (2002) who reported that there has been significant difference in weed density of various weed control practices and negatively affected the weed growth. Herbicides have significantly reduced the weed density in maize crop (Khan et al., 2003; Abdullah, 2007 and Hassan et al., 2010). Devender et al. (1998) who found that atrazine was the most effective herbicide for reducing weed density in maize. Khan $\boldsymbol{e t}$ al. (2012) found that the lowest weed density and dry weed biomass in plots were sprayed with atrazine while the highest weed density and dry weed biomass was found in control plots. Zimdahl (1999) mentioned that competition for water is often considered the most important source of weed-crop competition. Growing weeds with a crop have been shown to reduce soil moisture, although the depth of additional water extraction depends on the specific combination of crop and weeds present. Reductions in soil moisture have been related to increases in weed density or the length of time weeds remain present with the crop (Dalley et al., 2006). 
Table (5): Effect of herbicidal treatments on weed density and biomass of broad-leaved, grassy and total weeds in maize crop during 2016 and 2017 seasons.

\begin{tabular}{|c|c|c|c|c|c|c|c|c|c|c|c|c|c|c|c|c|c|c|c|}
\hline \multirow{3}{*}{ Treatments } & \multirow{3}{*}{ Rate/fed. } & \multicolumn{9}{|c|}{2016 season } & \multicolumn{9}{|c|}{2017 season } \\
\hline & & \multicolumn{3}{|c|}{ Broadleaf weeds } & \multicolumn{3}{|c|}{ Grassy weeds } & \multicolumn{3}{|c|}{ Total weeds } & \multicolumn{3}{|c|}{ Broadleaf weeds } & \multicolumn{3}{|c|}{ Grassy weeds } & \multicolumn{3}{|c|}{ Total weeds } \\
\hline & & W.D." & W.B. $* *$ & R.\% & W.D.* & W.B.*** & R.\% & W.D. & W.B.*** & R.\% | & W.D.* & W.B.** & R. $\%$ & W.D. ${ }^{*}$ & W.B.*** & R.\% & W.D. & W.B.*** & R.\% \\
\hline Starane & $200 \mathrm{~cm} 3$ & 7.00 & 11.33 & 96.43 & 4.33 & 9.33 & 90.70 & 11.33 & 15.99 & 95.21 & 15.00 & 26.00 & 94.95 & 4.33 & 11.33 & 87.50 & 19.33 & 31.66 & 92.45 \\
\hline Gesaprim & $600 \mathrm{~g}$ & 12.00 & 17.33 & 94.54 & 7.33 & 13.66 & $86.38 \mid$ & 19.33 & 21.32 & 93.17| & 15.99 & 29.66 & 91.53 & 6.00 & 10.00 & 88.96 & 21.99 & 35.66 & 91.26 \\
\hline Equip & $750 \mathrm{ml}$ & 10.33 & 22.99 & 92.76 & 3.66 & 4.33 & $95.68 \|$ & 13.99 & 27.32 & 93.27| & 20.32 & 41.33 & 89.62 & 3.00 & 5.33 & 94.12 & 23.32 & 46.66 & 88.87 \\
\hline Titus & $25 \mathrm{~g}$ & 26.65 & 70 & 77.98 & 6.00 & 17.33 & $82.72 \mid$ & 31.65 & 75.32 & 73.56 | & 34.98 & 87.31 & 75.05 & 7.33 & 15.66 & 82.72 & 42.31 & 102.97 & 75.45 \\
\hline $\begin{array}{l}\text { Merline } \\
\text { Extra }\end{array}$ & $50 \mathrm{~g}$ & 25.66 & 63.31 & 80.08 & $\mid$\begin{tabular}{||l}
$\mid 7.00$ \\
\end{tabular} & 15.00 & 85.04 & 32.66 & 70.31 & 75.10 & 36.65 & 86.31 & 77.91 & 6.00 & 13.00 & 85.66 & 42.65 & 90.31 & 78.47 \\
\hline Handhoeing & Twice & 30.66 & 87.33 & 68.51 & 11.33 & 29.66 & 70.43 & 41.99 & 86.65 & 72.88 & 49.65 & 120.00 & 66.60 & $|13.00|$ & 27.66 & 69.49 & 62.65 & 136.65 & 67.42 \\
\hline Untreated & ----- & 57.65 & 317.98 & --- & 22.66 & 100.33 & $\cdots$ & 80.31 & 326.98 & --- & 66.99 & 350.32 & --- & 20.00 & 90.66 & $\cdots$ & 86.99 & 419.49 & --- \\
\hline L.S.D 0.05 & & 5.21 & 7.66 & & 3.31 & 4.02 & & 7.98 & 10.16 & & 6.33 . & 9.45 & & 5.00 & 5.81 & & 9.65 & 13.47 & \\
\hline
\end{tabular}

W.D.* = weed density (No. $\left.\mathrm{m}^{-2}\right)$.

W.B. $* *$ weed fresh weight $\left(\mathrm{gm} \mathrm{m}^{-2}\right)$.

R. ${ }^{\circ} \%=$ Weed control efficiency. 


\section{Effect of herbicidal treatments on weed biomass \\ 1-Broad-leaved weeds:}

Results in (Tables 4 and 5) indicated that all herbicidal treatments significantly decreased biomass of broad-leaved weeds and gave high weed control efficiency (WCE) during the two studied seasons than untreated check. Maximum reduction in biomass of broadleaved weed was achieved with Starane treated plots followed by Equip and Gesaprim treatments in 2016 and 2017 seasons. Starane decreased biomass of these weeds by 96.43 and 94.95 \%in 2016 and 2017 seasons, respectively. While, Gesaprim gave 95.54 and 91.53\% WCE in 2016 and 2017 seasons, respectively. In addition, Epuip herbicide gave 92.76 and 89.62\% WCE during 2016 and 2017 seasons, respectively. While, Merline Extra, Titus treated plots and handhoeing treatment gave a moderate control of these weed compared to the control treatment.

\section{2-Grassy weed:}

Biomass of grassy weed effectively affected by all weed control treatments in maize field during 2016 and 2017 seasons in comparison with untreated check (Tables 4 and 5). Maximum reduction in grassy weed was noted with Equip treatment followed by Starane and Gesaprim treated plots during these studies, they gave 95.68, 90.70 and $86.38 \%$ WCE, respectively, in 2016 season, and 94.12, 87.50 and $88.96 \%$ WCE, respectively, in 2017 season compared to untreated plots. Moderate effect against Echonochloa colonum was observed with Titus, Merline Extra and hand hoeing during the two seasons.

\section{3-Total weeds:}

Data presented in (Tables 4 and 5) clearly indicated that all tested herbicides significantly $(\boldsymbol{p}=\mathbf{0 . 0 5})$ inhibited biomass of total weeds and gave high WCE compared with handhoeing treatment during 2016 and 2017 seasons. Starane found the best option in controlling the total weeds during the two seasons followed by Gesaprim and Equip treatments. Starane suppressed fresh weight of the total weeds by 94.95 and $92.45 \%$ during 2016 and 2017 seasons, respectively. Likewise, Gesaprim gave 91.53 and $91.26 \%$ WCE of the total weeds during the both tested seasons, respectively. In addition, Equip treated plots decreased fresh weight of the total weeds by 89.52 and $88.87 \%$, respectively, during the two experimental seasons. Merline Extra and Titus treated plots gave satisfactory control of the total weeds during this study, they gave 77.91 and $75.05 \%$ WCE in 2016 season, respectively, and 78.47 and $75.45 \%$ WCE, respectively, in 2017 season. The least effect against the total weeds biomass was observed with hand hoeing treatment compared to untreated plots, it reduced total weeds biomass by 66.60 and $67.42 \%$, respectively, during the two seasons. These results are in analogy with those reported by Helalia (1993), Muhammad et al., (2009), they reported that application of metolachlor, atrazine, fluroxpyr provided excellent control of weeds in maize fields. Likewise, Fluroxypyr, atrazine and foramisulfuron were the more 
effective treatments against the total weeds in maize crop (El-Metwally et al., 2012 and Pathak et al., 2015). Weed control in maize can be effectively achieved with foramisulfuron at the low rate (Kir and Dogan, 2009). The reduction in weed fresh weight may be due to the inhibition effect of herbicidal treatments on growth and development of weeds. Similar results were also reported by Pannacci and Covarelli (2009); Kir and Dogan (2009) and Hassan et al. (2010), Elias and Vasilis, (2017).

\section{Effect of herbicidal treatments on yield components of maize}

\section{1-Ear length (cm):}

Ear length $(\mathrm{cm})$ is very important yield determining factor of maize crop. Longer the ear length, lead to more number of grains per ear and higher yield. Statistical analysis of obtained data in (Table 6) show the effect of different herbicides and hand hoeing on ear length during 2016 and 2017 seasons. Obviously, all treated area with herbicides had significant increase in ear length compared to untreated plots. Starane, Gesaprim and Equip herbicides gave maximum increase in ear length during 2016 and 2017 seasons. Starane increased ear length by 23.51 and $21.86 \%$ in 2016 and 2017 season, respectively. Moreover, Gesaprim treated plots gave 22.01 and $21.63 \%$ increase in ear length in 2016 and 2017 season, respectively. Additionally, Equip treatment gave 22.40 and $21.30 \%$ increase in cob length during 2016 and 2017 season, respectively. Moderate increase in cob length was recorded with Merline Extra and Titus treated plots during the both seasons. Hand hoeing treatment gave poor increase in cob length compared to untreated plots. Ear length was significantly increased with all herbicidal treatments due to timely and efficiently weed control of weeds and may be less weed competition which allowed the maize plant to grow better and faster . These results are in harmony with those obtained by Singh and Singh (2003) and Stefanovic et al. (2004), who reported that greater cob length was found with application of weed control treatments and smallest cob length was observed with untreated plots. The cob length was highly significantly in herbicides treated plot was mainly due to timely and efficiently weed control of weeds and thus, less weed competition period in these treatments which allowed the maize plant to produce more photosynthetic material by using available nutrients.

These results are agreed with those reported by Singh and Singh (2003) and Stefanovic et al. (2004), who found that the greatest cob length was recorded in weed control treatments and smallest cob length in weedy check plots. Kamal et al. (1983) and Ali et al. (2003), they have reported the promotion of cob length when appropriate weed controlled treatments including herbicidal weed control was applied for weed control in maize crop.

\section{2- Ear weight (gm)}

Data listed in (Table 6) indicated that all weed control treatments significantly $(\boldsymbol{p}-\mathbf{= 0 . 0 5})$ increased ear weight (gm) during the two experimental seasons compared to control treatment. 
Results illustrated that minimum ear weight $(\mathrm{kg})$ was noticed in untreated check. On contrary, Starane, Gesaprim and Equip herbicides achieved maximum increase in ear weight during the two seasons, they gave 32.23, 29.41 and $30.99 \%$ increase in ear weight in 2016 season, respectively, and 30.65, 29.62 and $25.58 \%$, respectively, in 2017 season. Merline Extra treated plots recorded 25 and $26.73 \%$ increase in ear weight, respectively, during the two seasons. In addition, Titus treated plots recorded 22.16 and $20.39 \%$ increase in cob weight, respectively, in the two seasons. Least increase in ear weight was observed with hand hoeing treatment, it gave 17.71 and 14.41 increase in ear weight during the two consecutive seasons, respectively. Our results are in line with those reported by Soliman and Gharib (2011) who reported that all chemical and mechanical treatments resulted in a significant increase in ear length, ear diameter and ear grain weight in comparison with unwedded check.

Table (6): Effect of herbicidal treatments on yield components of maize crop during 2016 and 2017 seasons.

\begin{tabular}{|c|c|c|c|c|c|c|c|c|c|}
\hline \multirow[b]{2}{*}{ Treatments } & \multirow[b]{2}{*}{$\begin{array}{l}\text { Rate } \\
\text { /fed. }\end{array}$} & \multicolumn{4}{|c|}{2016 season } & \multicolumn{4}{|c|}{2017 season } \\
\hline & & $\begin{array}{c}\text { Ear } \\
\text { length } \\
(\mathrm{cm} .)\end{array}$ & $\begin{array}{c}\text { Increase } \\
\%\end{array}$ & $\begin{array}{c}\text { Ear } \\
\text { weight } \\
\text { (kg) }\end{array}$ & $\begin{array}{c}\text { Increase } \\
\%\end{array}$ & $\begin{array}{c}\text { Ear } \\
\text { length } \\
(\mathrm{cm} .)\end{array}$ & $\begin{array}{c}\text { Increase } \\
\%\end{array}$ & $\begin{array}{c}\text { Ear } \\
\text { weight } \\
(\mathbf{k g})\end{array}$ & $\begin{array}{c}\text { Increase } \\
\%\end{array}$ \\
\hline Starane & $200 \mathrm{~cm} 3$ & 24.45 & 23.51 & 425 & 32.23 & 23.87 & 21.86 & 411 & 30.65 \\
\hline Gesaprim & $600 \mathrm{~g}$ & 23.98 & 22.01 & 408 & 29.41 & 23.80 & 21.63 & 407 & 29.62 \\
\hline Equip & $750 \mathrm{ml}$ & 24.10 & 22.40 & 417 & 30.93 & 23.70 & 21.30 & 396 & 25.58 \\
\hline Titus & $25 \mathrm{~g}$ & 21.77 & 14.10 & 370 & 22.16 & 21.83 & 14.56 & 371 & 20.39 \\
\hline $\begin{array}{l}\text { Merline } \\
\text { Extra }\end{array}$ & $20 \mathrm{~g}$ & 22.35 & 16.33 & 384 & 25 & 22.60 & 17.47 & 389 & 26.73 \\
\hline Handhoeing & Twice & 21.55 & 13.22 & 350 & 17.71 & 21.44 & 13.01 & 333 & 14.41 \\
\hline Untreated & 0.00 & 18.70 & --- & 288 & --- & 18.65 & --- & 285 & --- \\
\hline $\begin{array}{l}\text { L.S.D. at } \\
0.05\end{array}$ & & \multicolumn{2}{|c|}{1.06} & \multicolumn{2}{|c|}{6.31} & \multicolumn{2}{|c|}{0.98} & \multicolumn{2}{|c|}{4.67} \\
\hline
\end{tabular}

\section{Effect of herbicides and handhoeing on maize grain yield ( $\left.\mathrm{kg} \mathrm{fed}^{-1}\right)$}

Data listed in (Table 7) illustrated the effect of weed control treatments on maize grain yield $\mathrm{kg} \mathrm{fed}^{-1}$ during 2016 and 2017 seasons. Results clearly indicated that all herbicidal treatments significantly $(P=0.05)$ increased maize grain yield compared to untreated check. Moreovere, least increase in maize grain yield was found in untreated plots during the two seasons. On contrary, Starane treated plots achieved highest increase in grain yield of maize followed by Gesaprim and Equip treatments during the two trials. Starane treatment gave 28 and $26.72 \%$ increase in maize grain yield in 2016 and 2017 seasons, respectively. Moreover, Gesaprim treated plots gave 27.56 and $25.95 \%$ increase during 2016 and 2017 seasons, respectively, over untreated plots. Also, Equip herbicide recorded 24.36 and $22.73 \%$ increase in the two seasons, respectively. Satisfactory increase in maize grains was achieved with Titus and Merline Extra treated plots, they gave 14.28 and $16.55 \%$ increase in 2016 season, respectively, and 16.07 and $18.11 \%$ increase in 2017 season, 
respectively .Poor increase in maize grains was observed with hand hoeing treatment during the two seasons compared to untreated plots. According to the data obtained from these studies, candidate herbicides showed maximum control of weeds in maize crop and gave higher WCE than untreated control, thereby improved plant growth characters and yield parameters and grains. Effect of candidate herbicides might be mainly due to their effect on weeds found in maize field leading to reduce competition between weeds and maize plants, which caused an increase in maize grain yield (Saad El-Din et al. 2004). Starane, Gesaprim and Equip treatments achieved excellent control of weeds as well as recorded maximum increase in maize yield. Dalley $\boldsymbol{e t}$ al. (2006) and Abouziena et al. (2007) reported that reduction in maize grain yield is about 66 to $90 \%$ due to weed infestation. Reduced maize grain yield is due to weeds may be attributed to several factors, e.g., competition between maize and weeds for water, nutrients and allelopathic effects of weeds. These results are in harmony with those obtained by Eleftherohorinos and Kotoula-Syka (1995) who concluded that application of herbicides doubled maize grain yields in comparison with the weed infested control. Hassan and Ahmed (2005) found that maize yield and yield components (ear length, ear weight, ear kernel weight and weight 100-grain weight) were increased with herbicides and hand hoeing as compared with unweeded control. As well, Abouziena et al. (2008) stated that all weed control treatments improved maize grain yield up to fold compared with nonweeded check. Hassan et al. (2010) found that herbicidal control of weeds considered one of the most effective control measures in maize fields. Grain yields were improved with fluroxypyr applied 6 week after sowing. However, the highest yields were obtained with hoeing treatment during the growing season. Whereas, Munsif et al. (2009) reported that weed control treatments significantly affected weed density, weeds flora, plant height, grain yield, biological yield and harvest index of maize crop, while, application of herbicides as foliar spray achieved lower weed density and higher biological yield and maximum plant height, grain yield and harvest index, whereas, weedy check occurred higher weed density, dwarf plants, lower biological, grain yields and harvest index. Higher grain yield in these treatments could be attributed to improved yield components such as higher number of grains cob, higher grain weight cob, and 100-grain weight. The improvement in yield components was intern due to improved growth attributes such higher total dry matter production and leaf area index. Thus, the improvement in growth and yield components was as a consequence of lower crop- weed competition, which shifted the balance in favour of crop in the utilization of nutrients, moisture, light and space (Walia et al, 2007, Inalli et al., 2014). Likewise, Tahir et al. (2009) found that the application of herbicides and manual hoeing increasing maize grain yield compared with untreated check. Khan (2002) and Subhan (2007) concluded that increased grain yield of maize crop by controlling weeds with application of herbicides. Similarly, Akmal et al. (2010) and Bibi et al. (2010) have found 
higher grain yield of maize in plots treated with herbicides. The lowest grain yield was recorded in weedy check could be attributed to maximum weed density which suppressed the growth and development of maize plants by competing for moisture, light and nutrients (Muhammad et al., 2009). The efficiency of various chemicals and other weed control practices in enhancing grain yield had also been observed by Toloraya et al. (2001) and Stefanovic et al. (2004). So, our study concluded that application of candidate herbicides and hand hoeing recorded high WCE of predominant weeds in maize field and increase grain yield and yield components of maize crop in comparison with unweeded check.

Table (7): Maize grain yield as influenced by different herbicidal treatments during 2016 and 2017 seasons.

\begin{tabular}{|c|c|c|c|c|c|}
\hline \multirow[b]{2}{*}{ Treatments } & \multirow[b]{2}{*}{ Rate fed $^{-1}$. } & \multicolumn{2}{|c|}{$\begin{array}{c}2016 \text { season } \\
\end{array}$} & \multicolumn{2}{|c|}{2017 season } \\
\hline & & $\begin{array}{c}\begin{array}{c}\text { Grain yield } \\
\left(\text { Kg plot }^{-1}\right)\end{array} \\
\end{array}$ & $\begin{array}{c}\text { Increase } \\
\% \\
\end{array}$ & $\begin{array}{c}\begin{array}{c}\text { Grain yield } \\
\left(\mathrm{Kg} \mathrm{plot}^{-1}\right)\end{array} \\
\end{array}$ & $\begin{array}{c}\text { Increase } \\
\% \\
\end{array}$ \\
\hline Starane & $200 \mathrm{~cm} 3$ & 25.00 & 28.00 & 24.20 & 26.57 \\
\hline Gesaprim & $600 \mathrm{~g}$ & 24.80 & 27.41 & 24.00 & 25.95 \\
\hline Equip & $750 \mathrm{ml}$ & 24.83 & 27.50 & 23.27 & 22.73 \\
\hline Titus & $25 \mathrm{~g}$ & $21 . .00$ & 14.28 & 21.47 & 16.07 \\
\hline Merline Extra & $20 \mathrm{~g}$ & 21.72 & 17.12 & 22.00 & 18.11 \\
\hline Handhoeing & Twice & 20.12 & 10.53 & 20.13 & 8.73 \\
\hline Untreated & 0.00 & 18.00 & $\begin{array}{ll}------ \\
\end{array}$ & 17.77 & ------- \\
\hline L.S.D. 0.05 & & \multicolumn{2}{|l|}{1.20} & \multicolumn{2}{|l|}{1.13} \\
\hline
\end{tabular}

\section{REFRENCES}

Abdelmonem, A.E. and R.M.A. El-Kholy (2006). Evaluation of chemical and mechanical control of annual weeds in maize fields. Annals of Agric. Sci., Moshtohor., 44 (4): 1889-1904.

Abdullah, E.A. (2007). Effect of planting methods and herbicides on yield and yield components of maize. M.Sc (Hons) Thesis, Agric.Univ.Peshawar, Pakistan.

Abouziena, H. F.; M. F. El-Karmany; M. Singh and S. D. Sharma (2007). Effect of nitrogen rates and weed control treatments on maize yield and associated weeds in sandy soils. Weed Technol., 21:1049-1053.

Abouziena, H. F.; I. M. El-Metwally and E. R. El-Desoki (2008). Effect of plant spacing and weed control treatments on maize yield and associated weeds in sandy soils. American-Eurasian J. Agric. and Environ. Sci., 4 (1): 9-17

Adigun, J.A. (2001).Control of weeds with pre-emergence herbicides in maizepepper mixture in the Nigerian northern Guinea Savanna: J. Sustainable Agri. Environ., 3: 378-383.

Akmal, M.; Ur-Rehman; H. Farhatullah; M. Asim and H. Akbar (2010). Response of maize varieties to nitrogen application for leaf area 
profile, crop growth, yield and yield components. Pak. J. Bot.,42(3):1941-1947.

Ali, R.; S.K. Khalil; S.M. Raza and H. Khan (2003). Effect of herbicides and row spacing on maize (Zea mays L.). Pak. J. Weed Sci. Res., 9(34):171-178.

Bibi, Z. ; N. Khan; M. Akram; Q. Khan; M.J. Khan; S. Batool and K. Makhdum. (2010). Integrating cultivars with reduced herbicides rates for weed management in maize. Pak. J. Bot., 42(3):1923-1929.

Bogdan, I.; P. Gus; I. Rusu and M. Hategan (2002). The chemical weed control with simple and complex herbicide in maize (Zea mays L.). Buletinul-universitatil-de-Stiinte-AgricoleSi-medicina-veterinaraCluj-Napoca-SeriaAgriculture. 57: 88-92.

Dalley, C. D.; M. L. Bernards and J. J. Kells (2006). Effect of weed removal timing and row spacing on soil moisture in corn (Zea mays).Weed Technol., 20:399-409.

Devender, S.; R.C. Tyagi; S.K. Agarwal and D. Singh (1998). Weed control methods in spring maize. Haryana Agric. Univ. J. Res., 28(1):21-25.

Eleftherohorinos, I.G. and E. Kotoula-Syka (1995). Influence of herbicide application rate and timings for post-emergence control of Sorghum halepense (L.) Pers. maize. Weed Res., 35 (2): 99-103.

Elias, T. and A. Vasilis (2017). Efficacy of the herbicide Lancelot 450 WG (Aminopyralid + Florasulam) on broadleaf and invasive weeds and effects on yield and quality parameters of maize.Agriculture,7(62):17.

El-Metwally, I.M.; M.S. Abd El-Salam; R.M.H. Tagour and H.F. Abouziena (2012). Efficiency of plant population and reduced herbicides rate on maize productivity and associated weeds. J. of Appl. Sci. Res., 8(4): 2342-2349.

Evans, P. S. (2003). Influence of nitrogen and duration of weed interference on corn growth and development. Weed Sci., 51(3): 456-566.

Ford, G. T. and J. Pleasant (1994). Competitive abilities of six corn (Zea mays L.) hybrids with four weed control practices. Weed Technol., 8 (3): 124-128.

Hafeezullah (2000). Effect of different sowing and weed control methods on the performance of sunflower. M.Sc. (Hons), thesis, Agric. Univ., Peshawer, Pakistan.

Hassan, A.A.A. and M.K.A. Ahmed (2005). The influence of some herbicides and additional hoeing in maize growth and yield and yield components. Int. J. Agri. Biol., 7(5): 708-710.

Hassan, G.; S. Tanveer; N. Khan and M. Munir (2010). Integrating cultivars with reduced herbicides rates for weed management in maize. Pak. J. Bot., 42(3): 1923-1929. 
Helalia, A.A.R. (1993). Chemical weed control in maize with some preemergence herbicides. Al-Azhar J. Agric. Res. , 18: 271-278.

Hoverstad, I. R.; J. L. Gunsolus; G. A. Johson and R. P. King (2004). Risk efficiency Criteria for evaluating economics of herbicides based weed management system in corn. Weed Technology, 18:687-697.

Inalli K.; B.N. A. Kumar and R. Babu (2014). Efficacy of Tank Mixture Herbicides for Weed Control in Maize. Trends in Biosciences., 7(14): 1835-1838.

Janjic, V.; D. Milosevic and I. Alovic (2004). Herbicides efficiency of sulfonylurea derivative and their combination without compounds in weed control in maize. Herbologia, 5: 41-51.

Kakade, S.U.; J.P. Deshmukh; V.M. Bhale; M.S. Solanke and P.V. Shingrup (2016). Efficacy of pre and post emergence herbicides in Maize. Extended Summaries Vol. 1: 4th International Agronomy Congress, Nov. 22-26, 2016, New Delhi, India. pp - 442-443.

Kamal, M.S.; M.S. Abdel-Raouf; E.A. Mahmoud and S. Amer (1983).Response of two maize varieties to different plant densities in relation to weed control treatments. Ann. Agric. Sci., 19:79-93.

Khan, M.A. (2002). Efficacy of different herbicides on the yield and yield components of maize. M.Sc (Hons) Thesis, Agric. Univ. Peshawar, Pakistan.

Khan, B.M.; N. Khan and I.A. Khan (2003). Efficacy of different herbicides on the yield and yield components of maize. Asian Net. Sci. Info. 3(2):300-304.

Khan, N.W.; N. Khan and I. A. Khan (2012). Integration of nitrogen fertilizers and herbicides for efficient weed management in maize crop. Sarhad J. Agric., 28(3):457-463.

Kir, K. and M. N. Dogan (2009). Weed control in maize (Zea mays L.) with effective minimum rates of foramsulfuron. Turk. J. Agric. For., 33: 601-610. Kudsk.

Kumar, B.; S. Prasad; D. Mandal and R. Kumar (2017). Influence of integrated weed management practices on weed dynamics, productivity and nutrient uptake of rabi maize (Zea mays L.). Int. J. of Current Microbio. and App. Sci., 6 (4): 1431-1440.

Lehoczky, E. A. and B. Nagy (2002). Effect of early competition between barnyardgrass (Echinochloa crus-galli L.) and maize on the growth of plants. Hungarian Weed Res. and Tech. 3 (1): 13- 20.

Muhammad, T.; R.J. Muhammad; T. Asif and A.N. Muhammad (2009). Effect of Different Herbicides on Weeds, Growth and Yield of Spring Planted Maize (Zea mays L.). Pak. j. life Soc. Sci., 7(2): 168-174.

Mukherje, P.K. and A. Rai (2015). Weed management in no-tilled dibbling maize within rice residue. 25th Asian-Pacific Weed Science Society Conference on "Weed Science for Sustainable Agriculture, 
Environment and Biodiversity", Hyderabad, India during 13-16 October, 2015. pg. 148.

Munsif, F.; K. Ali; I. Khan; H.U. Khan and M. Anwar (2009). Efficacy of various herbicides against weeds and their impact on yield of maize. Pak. J. Weed Sci. Res., 15(2-3): 191-198

Pannacci, E. and G. Covarelli (2009). Efficacy of mesotrione used at reduced doses for post-emergence weed control in maize (Zea mays L.). Crop Prot., 28: 57-61.

Pathak, P.K.; S. Singh; R.S. Rinwa and S. Singh (2015). Efficacy of different weed control methods in spring planted maize. Haryana J. Agron., 31 (1-2): 92-97.

Rana, S. S. (2017).Weed management in maize and maize-wheat cropping system. Department of Agronomy, CSK Himachal Pradesh Krishi Vishvavidyalaya, Palampur 176062, HP, India.

Roy, C.; F. Guggiari and J.M. Compagnon (2002). S-metolachlor; herbicide for maize, sorghum and sunflower. Syngenta Agro. SAS, Phytoma, France, No. 548: 51-53.

Rutta, A.; R. L. Vanderlip; R. A. Higgins; I. J. Moshier and A. M. Feyerherym (1991). Suitability of corn growth models for incorporation of weed and in set stress. Agron. J., 83: 757-763.

Saad El-Din, Samia, A.; Nadia K. Messiha and G.M. Metwally (2004). Response of maize and associated weeds to some post-emergence herbicides. J. Agric.Sci. Mansoura Univ. 29 (3): 1227-1237.

Singh, A.P. and P.C. Singh (2003). Effect of different weed control methods on growth and yield of rabisown hybrid maize cv. Hybrid 4640. J. Living World. 10: 12-15.

Skoko, H. and D. Zivanovic (2002). Weed control by herbicide in maize under agro-ecological conditions of Semberia. Weed Sci. Society of Bosnia and Herzegovina, 3:99-105.

Soliman, I.E. and H.S. Gharib (2011). Response of weeds and maize (Zea mays 1.)To some weed control treatments under different nitrogen fertilizer rates. Zagazig J. Agric. Res., 38 (2): 249-269.

Stanzen, L.; A. Kumar; B.C. Sharma; R. Puniya and A. Sharma (2016). Weed dynamics and productivity under different tillage and weedmanagement practices in maize (Zea mays) - wheat (Triticum aestivum) cropping sequence. Indian J. Agric., 61 (44): 449-454.

Steel, R.G.D. and J.H. Torrie (1984). Principles and Procedures of Statistics: A Biometrical Approach. 2nd McGraw Hill Book Co., Singapore.

Stefanovic, L.; M. Milivojevic; I. Husic; M. Samic and Z. Hojka (2004). Selectivity of the sulfonylurea herbicide group in the crop of commercial KL maize inbred lines. Institute-ze-Kukuruz, Herboglia, Serbis and Montenegro, 5(1): 53-63. 
Subhan, F. (2007). Response of Z.mays crop to various herbicides. Pakistan J Weed Sci Res., 13: 9-15.

Tahir, M.; M.R. Javed; A. Tanveer; M.A. Nadeem; A. Wasaya; S.A.H. Bukhari and J. Ur-Rehman (2009). Effect of different herbicides on weeds, growth and yield of spring planted maize (Zea mays L.). Pak. j. Life Soc. Sci., 7(2): 168-174.

Toloraya, T.R. ; V. P. Malakanova and M.G Akhtyrtsev (2001). Effectiveness of dates, methods and doses of applying Zinc Sulphate and its combination with the selective herbicides (Titus) in maize sowings. Kukuruza-ISerge. No.2:5-7.

Walia, U. S.; S. Singh and B. Singh (2007). Integrated control of hardy weeds in maize (Zea mays L.). Indian J. Weed Sci., 39 (1-2): 17-20.

Youssef, M.M.A. (1998). Efficacy of some weed control treatments on nematode populations in a maize field. Anz. Sch idlingskde, Pflanzenschutz, Umwehschutz 71,159-160, Blackwell WissenschaftsVerlag, Berlin.

Zimdah, R.L. (1999). Fundamentals of weed science. $2^{\text {nd }}$ ed. New Yourk. Acadimic Press, 209.

$$
\text { فاعلية مبيدات الحشائش فى حقول الأرة }
$$

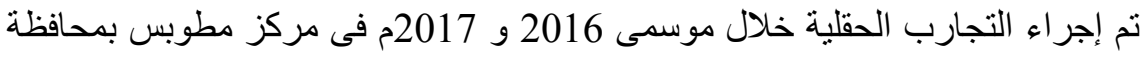

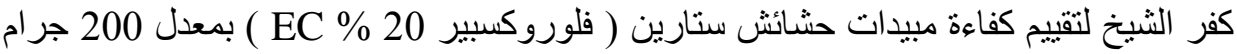
للفدان ، أتر ازين ( جيسابريم WP \% 90 WP ) بمعدل 600 جر ام للفدان ، إيكويب ( فور امسلفيرون

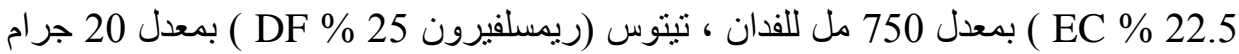

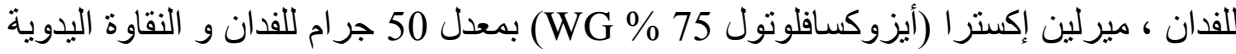

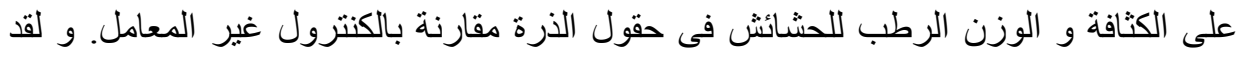

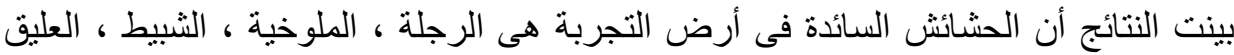
كعريضة الأوراق ، و أبو ركبة كرفيعة الأور اق خلافل موسمى الدر استة.

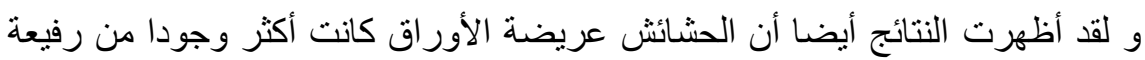

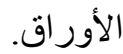

و لقد أكدت النتئج أن كل المبيدات المستخدمة و النقاوة اليدوية كانت فعالة بصورة معنوية فى مكافحة الحشائش و زيادة طول و سمك نباتات الذرة و كذللك زيادة محصول

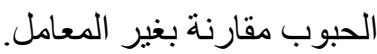

بوجه عام كان أكثر المبيدات فاعلية مبيد ستارين ، جيسابريم و إيكويب فى خفض ألئ أعداد

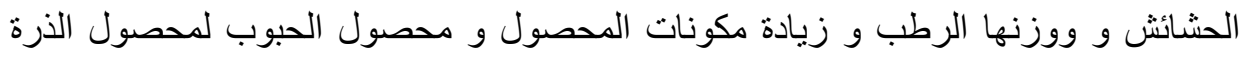

$$
\text { خلال موسمى الدراسة. }
$$

